\title{
Sphingobacterium composti sp. nov., isolated from cotton-waste composts
}

Correspondence

Hang-Yeon Weon

hyweon@rda.go.kr

\author{
Seung-Hee Yoo, ${ }^{1}$ Hang-Yeon Weon, ${ }^{2}$ Han-Byul Jang, ${ }^{1}$ Byung-Yong Kim, ${ }^{1}$ \\ Soon-Wo Kwon, ${ }^{1}$ Seung-Joo Go ${ }^{1}$ and Erko Stackebrandt ${ }^{3}$ \\ ${ }^{1}$ Korean Agricultural Culture Collection (KACC), Microbial Genetics Division, National Institute \\ of Agricultural Biotechnology, Rural Development Administration, Suwon 441-707, \\ Republic of Korea \\ ${ }^{2}$ Applied Microbiology Division, National Institute of Agricultural Science and Technology, \\ Rural Development Administration, Suwon 441-707, Republic of Korea \\ ${ }^{3}$ Deutsche Sammlung von Mikroorganismen und Zellkulturen $\mathrm{GmbH}$, Inhoffenstraße 7B, \\ 38124 Braunschweig, Germany
}

\begin{abstract}
A Gram-negative, strictly aerobic, short rod-shaped, non-motile bacterial strain designated $4 \mathrm{M} 24^{\top}$ was isolated from cotton-waste compost. Analysis of the $16 \mathrm{~S}$ rRNA gene sequence of strain $4 \mathrm{M} 24^{\top}$ revealed that it is a member of the genus Sphingobacterium, sharing 88.5-94.5\% sequence similarity with type strains of the genus Sphingobacterium and being most closely related to Sphingobacterium daejeonense TR6-04 ${ }^{\top}$ (94.5\% sequence similarity) and Sphingobacterium mizutaii ATCC $33299^{\top}$ (92.2\% similarity). The major fatty acids of strain $4 \mathrm{M} 24^{\top}$ grown on trypticase soy agar medium were summed feature 3 (iso- $\mathrm{C}_{15: 0} 2-\mathrm{OH}$ and/or $\mathrm{C}_{16: 1} \omega 7 c ; 37.5 \%$ ), iso- $\mathrm{C}_{15: 0}(29.5 \%)$ and iso- $\mathrm{C}_{17: 0} 3-\mathrm{OH}(19.7 \%)$. The $\mathrm{G}+\mathrm{C}$ content of the genomic DNA was $42.3 \mathrm{~mol} \%$. On the basis of phenotypic and genotypic characteristics, strain $4 \mathrm{M} 24^{\top}$ represents a novel species of the genus Sphingobacterium, for which the name Sphingobacterium composti sp. nov. is proposed. The type strain is $4 M 24^{\top}\left(=\operatorname{KACC} 11313^{\top}=\mathrm{DSM} 18850^{\top}\right)$.
\end{abstract}

Members of the genus Sphingobacterium Yabuuchi et al. 1983 have been isolated from Antarctic soil, clinical specimens (blood, urine and the uteruses of human patients) and compost composed of cow dung and rice straw (Holmes et al., 1982; Yabuuchi et al., 1983; Shivaji et al., 1992; Kim et al., 2006). To date, the following species have been described: Sphingobacterium antarcticum, Sphingobacterium daejeonense, Sphingobacterium faecium, Sphingobacterium mizutaii, Sphingobacterium multivorum, Sphingobacterium spiritivorum and Sphingobacterium thalpophilum (Yabuuchi et al., 1983; Shivaji et al., 1992; Takeuchi \& Yokota, 1992; Kim et al., 2006). Cotton-waste composts are used as media for the cultivation of oyster mushrooms (Pleurotus ostreatus) in Korea. During the composting process, the compost temperature is gradually increased to $65^{\circ} \mathrm{C}$. Strain $4 \mathrm{M} 24^{\mathrm{T}}$ was isolated by plating on trypticase soy agar (TSA, $\mathrm{pH}$ 7.0; Difco) at $30^{\circ} \mathrm{C}$; cultures were maintained on TSA medium.

The morphological, physiological and biochemical characteristics of strain $4 \mathrm{M} 24^{\mathrm{T}}$ were investigated using routine cultivation on TSA medium at $30^{\circ} \mathrm{C}$. Gram staining, catalase and oxidase activities, and hydrolysis of casein,

The GenBank accession number for the 16S rRNA gene sequence of strain $4 M 24^{\top}$ is EF122436. chitin, CM-cellulose, DNA, gelatin, starch, Tweens 20, 40 and 80 , and tyrosine were investigated as described by Smibert \& Krieg (1994). Growth was assessed at 5, 10, 20, 25, $30,37,40,45$ and $50{ }^{\circ} \mathrm{C}$, at $\mathrm{pH} 4,5,6,7,8,9$ and 10 , and at $0,1,3,5$ and $7 \% \mathrm{NaCl}$. The strain was additionally characterized using the whole test spectrum of the API 20NE, API ID 32 GN and API ZYM systems (bioMérieux) according to the manufacturer's instructions. Sensitivity to antibiotics was determined with the routine disc-diffusion plate method. The following antibiotics were tested: ampicillin $(10 \mu \mathrm{g})$, benzylpenicillin $(10 \mu \mathrm{g})$, carbenicillin $(100 \mu \mathrm{g})$, gentamicin $(10 \mu \mathrm{g})$, kanamycin $(30 \mu \mathrm{g})$, lincomycin $(15 \mu \mathrm{g})$, neomycin $(30 \mu \mathrm{g})$, oleandomycin, polymyxin (300 U), streptomycin $(10 \mu \mathrm{g})$ and tetracycline $(30 \mu \mathrm{g})$.

Cells were harvested after $48 \mathrm{~h}$ growth on TSA medium, and the identification of fatty acids was performed according to the standard protocol of the Microbial Identification System (MIDI; Microbial ID). The DNA G + C content was determined according to the method of Mesbah et al. (1989), using a reversed-phase column (Supelcosil LC-18-S; Supelco).

The 16S rRNA gene of strain $4 \mathrm{M} 24^{\mathrm{T}}$ was amplified using PCR with primers fD1 and rP2 (Weisburg et al., 1991); the entire PCR fragment was directly sequenced (Hiraishi, 1992). For phylogenetic analyses, the 16S rRNA gene 
sequences of the type strains of Sphingobacterium species (and Pedobacter heparinus DSM $2366^{\mathrm{T}}$, serving as an outgroup) were used. The $16 \mathrm{~S}$ rRNA gene sequences were aligned using the MEGALIGN program (DNASTAR). A phylogenetic tree was constructed using the neighbour-joining method of Saitou \& Nei (1987) in MEGA, version 3 (Kumar et al., 2004). The stability of relationships was assessed by performing bootstrap analyses of the neighbour-joining data, based on 1000 resamplings. The phylogenetic analyses were also assessed using maximum-parsimony analysis.

The cells of strain $4 \mathrm{M} 24^{\mathrm{T}}$ were found to be Gram-negative, non-motile short rods. The phenotypic and chemotaxonomic characteristics that differentiate strain $4 \mathrm{M} 24^{\mathrm{T}}$ from previously described Sphingobacterium species are listed in Table 1.

The major fatty acids were summed feature 3 (iso- $\mathrm{C}_{15: 0}$ $2-\mathrm{OH}$ and/or $\left.\mathrm{C}_{16: 1} \omega 7 c, 37.5 \%\right)$, iso- $\mathrm{C}_{15: 0}(29.5 \%)$ and iso- $\mathrm{C}_{17: 0} 3-\mathrm{OH}(19.7 \%)$, which is a scenario common to all strains except S. antarcticum MTCC $675^{\mathrm{T}}$. However, some differences in the proportions of the fatty acids could be observed between strain $4 \mathrm{M} 24^{\mathrm{T}}$ and its phylogenetically closest relative, S. daejeonense TR6-04 $4^{\mathrm{T}}$. Fatty acids anteiso$\mathrm{C}_{15: 0}$, iso- $\mathrm{C}_{16: 0}$ and $\mathrm{C}_{17: 0} 2-\mathrm{OH}$ were absent from strain $4 \mathrm{M} 24^{\mathrm{T}}$, but each represented $>2 \%$ of the fatty acid content of $S$. daejeonense TR6- $04^{\mathrm{T}}$. The cellular fatty acid profiles of strain $4 \mathrm{M} 24^{\mathrm{T}}$ and Sphingobacterium species are presented in Table 2. The DNA G $+\mathrm{C}$ content for the genus Sphingobacterium ranges from 37.3 to $44.2 \mathrm{~mol} \%$. The DNA G+C content of strain $4 \mathrm{M} 24^{\mathrm{T}}(42.3 \mathrm{~mol} \%)$ was within this range.

An almost-complete 16S rRNA gene sequence of strain $4 \mathrm{M} 24^{\mathrm{T}}$ was obtained (1470 bp). Preliminary sequence comparisons with $16 \mathrm{~S}$ rRNA gene sequences deposited in the GenBank database indicated that our isolate belonged to the genus Sphingobacterium of the Bacteroidetes. Strain $4 \mathrm{M} 24^{\mathrm{T}}$ showed sequence similarities of $88.5-94.4 \%$ with respect to type strains of the genus Sphingobacterium. The closest relative was $S$. daejeonense TR6-04 ${ }^{\mathrm{T}}$ (94.4\%). According

Table 1. Differential characteristics of strain $4 \mathrm{M} 24^{\top}$ and related members of the genus Sphingobacterium

Strains: 1, 4M24 ${ }^{\mathrm{T}} ; 2$, S. daejeonense TR6-04 ${ }^{\mathrm{T}}$ (Kim et al., 2006); 3, S. spiritivorum NBRC $14948^{\mathrm{T}} ; 4$, S. multivorum NBRC $14947^{\mathrm{T}}$; 5, S. mizutaii ATCC $33299^{\mathrm{T}}$; 6, S. thalpophilum NBRC $14963^{\mathrm{T}}$; 7, S. faecium NBRC $15299^{\mathrm{T}}$ [data in columns 3-7 are from Takeuchi \& Yokota (1992) and Steyn et al. (1998)]; 8, S. antarcticum MTCC $675^{\mathrm{T}}$ (Shivaji et al., 1992). All strains are positive for aerobic growth at $30^{\circ} \mathrm{C}$, catalase and oxidase activities and the assimilation of D-glucose, D-mannose, D-maltose and sucrose. All strains are negative for Gram staining, sporulation, indole production, motility, assimilation of acetate and acid production from inositol. With the exception of $S$. antarcticum MTCC $675^{\mathrm{T}}$, all strains are positive for the assimilation of $\mathrm{N}$-acetyl-D-glucosamine and salicin, and for acid production from Dmelibiose and amygdalin. All strains are negative for the assimilation of $\mathrm{D}$-fucose, gluconate, propionate, valerate, caprate, phenylacetate, 3-hydroxybenzoate, malate, itaconate, adipate, suberate and L-alanine (data are not reported for $S$. antarcticum). +, Positive; -, negative; V, variable; ND, no data available.

\begin{tabular}{|c|c|c|c|c|c|c|c|c|}
\hline Characteristic & 1 & 2 & 3 & 4 & 5 & 6 & 7 & 8 \\
\hline \multicolumn{9}{|l|}{ Growth at: } \\
\hline $5^{\circ} \mathrm{C}$ & - & - & - & - & - & - & + & + \\
\hline $42^{\circ} \mathrm{C}$ & + & + & - & - & - & + & - & - \\
\hline Acid production from D-glucose & - & + & + & + & + & + & + & + \\
\hline \multicolumn{9}{|l|}{ Hydrolysis of: } \\
\hline DNA & - & - & + & + & + & - & + & $\mathrm{ND}$ \\
\hline Starch & - & - & + & + & + & + & + & - \\
\hline Aesculin & + & - & + & + & + & + & + & + \\
\hline Gelatin & - & - & - & - & - & - & - & + \\
\hline Urease & - & - & + & + & + & + & + & + \\
\hline \multicolumn{9}{|l|}{ Assimilation of: } \\
\hline L-Rhamnose & - & - & + & + & - & + & + & + \\
\hline L-Arabinose & + & - & - & + & $\mathrm{v}$ & + & + & + \\
\hline D-Mannitol & - & - & + & - & - & - & - & + \\
\hline D-Melibiose & + & + & + & + & + & + & + & - \\
\hline \multicolumn{9}{|l|}{ Acid production from: } \\
\hline L-Rhamnose & - & - & - & $\mathrm{V}$ & - & + & - & - \\
\hline L-Arabinose & + & - & - & + & + & + & + & - \\
\hline DNA G $+\mathrm{C}$ content $(\mathrm{mol} \%)$ & 42.3 & 38.7 & 39.0 & $39.9-40.5$ & $39.3-40.0$ & $44.0-44.2$ & 37.3 & 39.3 \\
\hline
\end{tabular}


Table 2. Cellular fatty acid composition of strains $4 \mathrm{M} 24^{\top}$ and Sphingobacterium species

Strains: $1,4 \mathrm{M} 24^{\mathrm{T}} ; 2$, S. daejeonense TR6- $04^{\mathrm{T}} ; 3$, S. mizutaii DSM $11724^{\mathrm{T}}$ (data in columns $1-3$ are from this study); 4, S. spiritivorum NBRC $14948^{\mathrm{T}}$; 5, S. multivorum $\mathrm{NBRC} 14947^{\mathrm{T}}$; 6, S. thalpophilum NBRC $14963^{\mathrm{T}}$; 7, S. faecium NBRC $15299^{\mathrm{T}}$ (data in columns 4-7 are from Steyn et al., 1998); 8. S. antarcticum MTCC $675^{\mathrm{T}}$ (Shivaji et al., 1992). +, Fatty acid detected but its content was not reported; -, not detected or $<1 \%$.

\begin{tabular}{|c|c|c|c|c|c|c|c|c|}
\hline Fatty acid & 1 & 2 & 3 & 4 & 5 & 6 & 7 & 8 \\
\hline $\mathrm{C}_{14: 0}$ & - & - & - & 1.0 & 2.7 & 3.2 & - & + \\
\hline anteiso- $\mathrm{C}_{15: 0}$ & - & 4.1 & 2.3 & - & - & - & - & - \\
\hline iso- $\mathrm{C}_{15: 0}$ & 29.5 & 26.1 & 27.4 & 30.1 & 22.2 & 17.7 & 24.6 & 29.0 \\
\hline iso- $\mathrm{C}_{15: 0} 3-\mathrm{OH}$ & 2.3 & 1.3 & 1.4 & 2.2 & 3.2 & 4.3 & 3.7 & - \\
\hline iso- $\mathrm{C}_{15: 1} \mathrm{G}$ & - & 1.2 & 1.2 & - & - & - & - & - \\
\hline $\mathrm{C}_{16: 0}$ & 2.2 & 2.0 & 2.3 & 3.5 & 7.8 & 6.0 & 4.5 & + \\
\hline $\mathrm{C}_{16: 0} 2-\mathrm{OH}$ & - & - & - & - & - & 3.2 & - & - \\
\hline $\mathrm{C}_{16: 0} 3-\mathrm{OH}$ & 1.2 & - & 1.0 & 2.7 & 5.3 & 6.3 & 2.1 & - \\
\hline $\mathrm{C}_{16: 0}$ 10-methyl & - & - & - & - & - & - & 1.4 & - \\
\hline iso- $\mathrm{C}_{16: 0}$ & - & 2.3 & 1.6 & - & - & - & - & - \\
\hline iso- $\mathrm{C}_{16: 0} 3-\mathrm{OH}$ & - & 1.6 & - & - & - & - & - & - \\
\hline iso- $\mathrm{C}_{16: 1} \mathrm{H}$ & - & 1.0 & - & - & - & - & - & - \\
\hline $\mathrm{C}_{16: 1} \omega 5 c$ & - & - & - & - & - & - & 1.5 & - \\
\hline $\mathrm{C}_{17: 0} 2-\mathrm{OH}$ & - & 2.4 & 1.4 & - & - & - & - & - \\
\hline iso- $\mathrm{C}_{17: 0} 3-\mathrm{OH}$ & 19.7 & 17.3 & 17.4 & 12.5 & 7.1 & 10.0 & 10.0 & - \\
\hline $\mathrm{C}_{17: 1}$ & - & - & - & - & - & - & - & + \\
\hline $\mathrm{C}_{18: 1} \omega 7 c$ & - & 1.0 & - & - & - & - & - & - \\
\hline iso- $\mathrm{C}_{17: 1} \omega 9 \mathrm{c}$ & 2.9 & 3.5 & 3.6 & 1.7 & - & - & - & - \\
\hline Summed feature $3^{*}$ & 37.5 & 29.8 & 33.6 & 42.7 & 49.0 & 47.8 & 48.1 & 56.0 \\
\hline $\begin{array}{l}\text { Unknown (ECL } \\
13.566) \dagger\end{array}$ & - & - & - & - & - & 1.3 & 1.4 & - \\
\hline
\end{tabular}

${ }^{*}$ Summed feature 3 contains $\mathrm{C}_{16: 1} \omega 7 c /$ iso- $\mathrm{C}_{15: 0} 2-\mathrm{OH}$.

$\dagger$ ECL, Equivalent chain-length. to the phylogenetic tree (Fig. 1), strain $4 \mathrm{M} 24^{\mathrm{T}}$ forms a compact cluster with $S$. daejeonense and S. mizutaii.

On the basis of our phenotypic and phylogenetic studies, it is clear that strain $4 \mathrm{M} 24^{\mathrm{T}}$ represents a member of the genus Sphingobacterium. Therefore, we conclude that strain $4 \mathrm{M} 24^{\mathrm{T}}$ represents a novel species of the genus Sphingobacterium, for which the name Sphingobacterium composti sp. nov. is proposed.

\section{Description of Sphingobacterium composti sp. nov.}

Sphingobacterium composti (com.pos'ti. N.L. gen. n. composti of compost).

Cells are Gram-negative, non-motile rods, $0.5-0.6 \mu \mathrm{m}$ long by $1.0-2.0 \mu \mathrm{m}$ wide. Colonies grown on TSA are yellow, circular and convex with entire margins. The temperature, $\mathrm{pH}$ and $\mathrm{NaCl}$ ranges for growth are $10-45^{\circ} \mathrm{C}, \mathrm{pH}$ 6-9 and $0-5 \% \mathrm{NaCl}$, respectively. Nitrate is not reduced. Indole is not produced. Glucose is not fermented. Catalase, oxidase, arginine dihydrolase, $\beta$-galactosidase, alkaline phosphatase, esterase lipase (C8), leucine arylamidase, valine arylamidase, acid phosphatase, naphthol-AS-BI-phosphohydrolase, $\alpha$-glucosidase, $\beta$-glucosidase and $N$-acetyl- $\beta$-glucosaminidase activities are present. Negative for esterase (C4), lipase (C14), cystine arylamidase, trypsin, $\alpha$-chymotrypsin, $\alpha$-galactosidase, $\beta$-glucuronidase, $\alpha$-mannosidase and $\alpha$-fucosidase activities. Hydrolyses Tweens 20 and 80 . Does not hydrolyse aesculin, casein, chitin, CM-cellulose, DNA, gelatin, starch, Tween 40, tyrosine or urea. Assimilates D-glucose, L-arabinose, D-mannose, $\mathrm{N}$-acetylglucosamine, D-maltose, D-sucrose, salicin and D-melibiose. Does not assimilate D-mannitol, potassium gluconate, capric acid, adipic acid, malic acid, trisodium citrate, phenylacetic acid, L-rhamnose, D-ribose, inositol, itaconic acid, suberic acid, sodium malonate, sodium acetate, lactic acid, L-

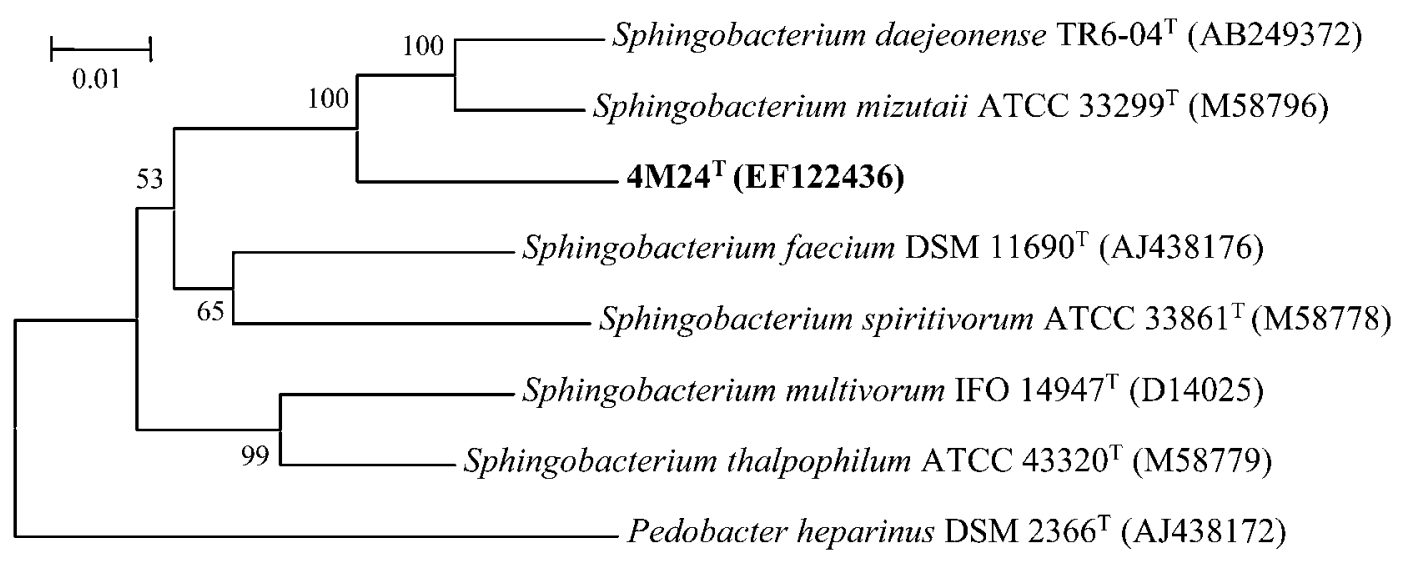

Fig. 1. Phylogenetic tree generated using the distance matrix and neighbour-joining method based on the $16 \mathrm{~S}$ rRNA gene sequence of strain $4 \mathrm{M} 24^{\top}$. Numbers at nodes represent bootstrap percentages based on 1000 samplings. Bar, 0.01 changes per nucleotide position. 
alanine, potassium 5-ketogluconate, glycogen, 3-hydroxybenzoic acid, L-serine, L-fucose, D-sorbitol, propionic acid, valeric acid, L-histidine, potassium 2-ketogluconate, 3-hydroxybutyric acid, 4-hydroxybenzoic acid or L-proline. Acids are produced from D-arabinose, L-arabinose, D-galactose, D-glucose, D-fructose, D-mannose, methyl $\alpha$-D-mannopyranoside, methyl $\alpha$-D-glucopyranoside, amygdalin, arbutin, salicin, D-cellobiose, D-maltose, D-lactose, D-sucrose, D-raffinose and L-fucose. Acids are produced weakly from D-xylose, D-melibiose, D-trehalose and gentiobiose. Acids are not produced from glycerol, erythritol, D-ribose, L-xylose, D-adonitol, methyl $\beta$-D-xylopyranoside, L-sorbose, L-rhamnose, dulcitol, inositol, D-mannitol, D-sorbitol, $\mathrm{N}$-acetylglucosamine, inulin, D-melezitose, starch, glycogen, xylitol, D-turanose, D-lyxose, D-tagatose, D-fucose, D-arabitol, Larabitol, potassium gluconate, potassium 2-ketogluconate or potassium 5-ketogluconate. Resistant to ampicillin $(10 \mu \mathrm{g})$, benzylpenicillin $(10 \mu \mathrm{g})$, gentamicin $(10 \mu \mathrm{g})$, kanamycin $(30 \mu \mathrm{g})$, lincomycin $(15 \mu \mathrm{g})$, neomycin $(30 \mu \mathrm{g})$, oleandomycin, polymyxin $(300 \mathrm{U})$ and streptomycin $(10 \mu \mathrm{g})$. Sensitive to carbenicillin $(100 \mu \mathrm{g})$ and tetracycline $(30 \mu \mathrm{g})$. The major fatty acids are summed feature 3 (iso- $\mathrm{C}_{15: 0} 2-\mathrm{OH}$ and/or $\mathrm{C}_{16: 1}(\omega 7 c)$, iso- $\mathrm{C}_{15: 0}$ and iso- $\mathrm{C}_{17: 0} 3-\mathrm{OH}$. The $\mathrm{G}+\mathrm{C}$ content of the genomic DNA is $42.3 \mathrm{~mol} \%$.

The type strain, $4 \mathrm{M} 24^{\mathrm{T}}\left(=\right.$ KACC $11313^{\mathrm{T}}=$ DSM $\left.18850^{\mathrm{T}}\right)$, was isolated from cotton-waste composts in South Korea.

\section{Acknowledgements}

This study was carried out with the support of the programme of international joint research by the Rural Development Administration (South Korea) and the Deutsche Sammlung von Mikroorganismen und Zellkulturen GmbH (Braunschweig, Germany).

\section{References}

Hiraishi, A. (1992). Direct automated sequencing of $16 \mathrm{~S}$ rDNA amplified by polymerase chain reaction from bacterial cultures without DNA purification. Lett Appl Microbiol 15, 210-213.
Holmes, B., Owen, R. J. \& Hollis, D. G. (1982). Flavobacterium spiritivorum, a new species isolated from human clinical specimens. Int J Syst Bacteriol 32, 157-165.

Kim, K.-H., Ten, L. N., Liu, Q.-M., Im, W.-T. \& Lee, S.-T. (2006). Sphingobacterium daejeonense sp. nov., isolated from a compost sample. Int J Syst Evol Microbiol 56, 2031-2036.

Kumar, S., Tamura, K. \& Nei, M. (2004). MEGA3: integrated software for molecular evolutionary genetics analysis and sequence alignment. Brief Bioinform 5, 150-163.

Mesbah, M., Premachandran, U. \& Whitman, W. B. (1989). Precise measurement of the $\mathrm{G}+\mathrm{C}$ content of deoxyribonucleic acid by highperformance liquid chromatography. Int J Syst Bacteriol 39, 159-167.

Saitou, N. \& Nei, M. (1987). The neighbor-joining method: a new method for reconstructing phylogenetic trees. Mol Biol Evol 4, 406-425.

Shivaji, S., Ray, M. K., Rao, N. S., Saisree, L., Jagannadham, M. V., Kumar, G. S., Reddy, G. S. N. \& Bhargava, P. M. (1992). Sphingobacterium antarcticus sp. nov., a psychrotrophic bacterium from the soils of Schirmacher Oasis, Antarctica. Int J Syst Bacteriol 42, 102-106.

Smibert, R. M. \& Krieg, N. R. (1994). Phenotypic characterization. In Methods for General and Molecular Bacteriology, pp. 607-654. Edited by P. Gerhardt, R. G. E. Murray, W. A. Wood \& N. R. Krieg. Washington, DC: American Society for Microbiology.

Steyn, P. L., Segers, P., Vancanneyt, M., Sandra, P., Kersters, K. \& Joubert, J. J. (1998). Classification of heparinolytic bacteria into a new genus, Pedobacter, comprising four species: Pedobacter heparinus comb. nov., Pedobacter piscium comb. nov., Pedobacter africanus sp. nov. and Pedobacter saltans sp. nov. Proposal of the family Sphingobacteriaceae fam. nov. Int J Syst Bacteriol 48, 165-177.

Takeuchi, M. \& Yokota, A. (1992). Proposals of Sphingobacterium faecium sp. nov., Sphingobacterium piscium sp. nov., Sphingobacterium heparinum comb. nov., Sphingobacterium thalpophilum comb. nov. and two genospecies of the genus Sphingobacterium, and synonymy of Flavobacterium yabuuchiae and Sphingobacterium spiritivorum. J Gen Appl Microbiol 38, 465-482.

Weisburg, W. G., Barns, S. M., Pelletier, D. A. \& Lane, D. J. (1991). $16 \mathrm{~S}$ ribosomal DNA amplification for phylogenetic study. J Bacteriol 173, 697-703.

Yabuuchi, E., Kaneko, T., Yano, I., Moss, C. W. \& Miyoshi, N. (1983). Sphingobacterium gen. nov., Sphingobacterium spiritivorum comb. nov., Sphingobacterium multivorum comb. nov., Sphingobacterium mizutae sp. nov., and Flavobacterium indologenes sp. nov.: glucosenonfermenting Gram-negative rods in CDC groups IIK-2 and IIb. Int J Syst Bacteriol 33, 580-598. 